\title{
The "Phoenix" Rises from Its Ashes
}

The year 2018 was a watershed year of downs for the Indian Journal of Medical and Paediatric Oncology (IJMPO), but 2019 beckons the arising of the "Phoenix" from its ashes.

A new-look journal with a new philosophy along with a new set of editorial board members and reviewers. The journal, an official publication of the Indian Society of Medical and Paediatric Oncology, is directed to caring of cancer patients with or at risk of cancer, which is to advance excellence in oncology treatment and quality of cancer care.

The aim of this journal as set forth by the new editor-in-chief and his team is evidence-based content for oncology care providers. The decision is to have clear, concise, comprehensive, and well-referenced articles.

All manuscripts that have been or will be submitted to IJMPO must only be under the consideration of the Journal. The articles must be original and nonplagiarised. All the submitted articles are subjected to plagiarism check and peer review, and the articles will be judged on the quality of work and suitability for IJMPO audience.

The editors support the principles of financial disclosures and are taking steps to ensure that all stakeholders understand and comply with its policy. The journal is also looking forward to a robust privacy policy. Already submitted and accepted articles previously will also be subjected to the same rigor.

The dynamics of the editorial board and the vibrancy of the young editorial board in whom the society has placed its trust will take the Journal to the next echelon and we enter the world of "Write in India; Publish in India; Index Globally."

I look forward to a literacy feast in scientific medical writing.

Gouri Shankar Bhattacharyya

Salt Lake City Medical Centre, Kolkata, West Bengal, India

Address for correspondence:

Dr. Gouri Shankar Bhattacharyya,

Salt Lake City Medical Centre, Kolkata, West Bengal, India.

E-mail:docgs@hotmail.com

This is an open access journal, and articles are distributed under the terms of the Creative Commons Attribution-NonCommercial-ShareAlike 4.0 License, which allows others to remix, tweak, and build upon the work non-commercially, as long as appropriate credit is given and the new creations are licensed under the identical terms.

\begin{tabular}{|l|l|}
\hline \multicolumn{2}{|c|}{ Access this article online } \\
\hline Quick Response Code: & Website: \\
\hline & www.ijmpo.org \\
\cline { 2 - 2 } & DOI: \\
\hline
\end{tabular}

How to cite this article: Bhattacharyya GS. The "Phoenix" rises from its ashes. Indian J Med Paediatr Oncol 2019;40:2. 